ORIGINAL ARTICLE

\title{
Markers of apoptosis in stage IB squamous cervical carcinoma
}

\author{
G Van de Putte, R Holm, A K Lie, M Baekelandt, G B Kristensen
}

See end of article for

authors' affiliations

J Clin Pathol 2005;58:590-594. doi: 10.1136/jcp.2004.021220

.....................

Correspondence to: Dr G Van de Putte, Department of Gynaecological Oncology, The Norwegian Radium Hospital, Montebello, 0310 Oslo, Norway; gregg.marijke@ pandora.be

Accepted for publication 4 December 2004

\begin{abstract}
Aims: To examine the prognostic relevance of the expression of the $\mathrm{Bcl}-2, \mathrm{Bcl}-\mathrm{x}_{\mathrm{L}}$, and Bax proteins in stage IB squamous cervical carcinoma (SCC).

Methods: In total, 220 patients who underwent radical hysterectomy and bilateral lymphadenectomy at the Norwegian Radium Hospital for stage IB SCC between 1987 and 1993 were studied. Immunohistochemistry using monoclonal antibodies against $\mathrm{Bcl}-2, \mathrm{Bcl}-\mathrm{x}_{\mathrm{L}}$, and $\mathrm{Bax}$ was used to examine protein expression. Ten patients who underwent hysterectomy for uterine prolapse served as controls. Results: Cytoplasmic expression of $\mathrm{Bcl}-2, \mathrm{Bcl}-\mathrm{x}_{\mathrm{L}}$, and Bax was low ( $<5 \%$ positive cells) in 159 of 220 $(73 \%), 193$ of $220(87 \%)$, and 39 of $220(18 \%)$ tumours, respectively, and high ( $\geqslant 5 \%$ positive cells) in 61 of $220(27 \%), 27$ of $220(13 \%)$, and 181 of $220(82 \%)$ tumours, respectively. In univariate analysis, all classic clinicopathological parameters but none of the investigated proteins were associated with prognosis. In multivariate analysis, only deep stromal invasion was independently related to survival. Conclusion: $\mathrm{Bcl}-2, \mathrm{Bcl}-\mathrm{x}_{\mathrm{L}}$, and Bax were not independently associated with prognosis in stage IB SCC.
\end{abstract}

$\mathrm{S}$ ince apoptosis, or programmed cell death, was described in $1972,{ }^{1}$ and since it was recognised that cell proliferation and cell survival are regulated by different pathways, ${ }^{2}$ cell death has become a topic of great interest in cancer research. This discovery has made it clear that tumorigenesis not only depends on proliferation but equally on the potential of a cell to resist cell death (apoptosis). Apoptosis thus became a new target for treatment. In addition, the DNA damage caused by chemotherapy and radiotherapy leads to apoptosis. Resistance to apoptosis, present in many tumours, could possibly explain why antitumour treatment sometimes fails. Restoring apoptosis could then be a means of drastically improving the effectiveness of existing treatment.

"It would be useful to identify prognostic factors that could help target adjuvant treatment"

Members of the Bcl-2 family of proteins are key regulators of apoptosis. They are divided into prosurvival proteins that can inhibit apoptosis, such as Bcl-2 and $\mathrm{Bcl}-\mathrm{X}_{\mathrm{L}}$, and proapoptotic members, such as Bax. Bcl-2 has been identified as the gene activated by the $\mathrm{t}(14 ; 18)(\mathrm{q} 32 ; \mathrm{q} 21)$ translocation in $\mathrm{B}$ cell follicular lymphoma and leukaemia, thereby demonstrating its oncogenic potential. ${ }^{3} \mathrm{Bcl}-2$ enhances cell survival by inhibiting apoptosis induced under a wide range of stimuli. ${ }^{4}$ Transfection of the Bcl-2 gene into different cell lines confers increased resistance to several cytostatic drugs. ${ }^{5}$ Alternative splicing of Bcl-x, identified in 1993, results in two distinct protein products. The larger, $\mathrm{Bcl}-\mathrm{x}_{\mathrm{L}}$, is similar in size and structure to Bcl-2 and is antiapoptotic. In contrast, the smaller, $\mathrm{Bcl}-\mathrm{X}_{\mathrm{S}}$, inhibits $\mathrm{Bcl}-2$ and thus is proapoptotic. In vivo, strong expression of $\mathrm{Bcl}-\mathrm{x}_{\mathrm{S}}$ is seen in cells with a high turnover, such as developing lymphocytes. In contrast, Bcl- $\mathrm{X}_{\mathrm{L}}$ is found in tissues containing long lived postmitotic cells, such as adult brain. ${ }^{6}$ Bax (Bcl-2 associated protein $\mathrm{X}$ ) is probably the most important member of the proapoptotic proteins. It inhibits $\mathrm{Bcl}-2$ but can also directly induce apoptosis. ${ }^{7}$ Proapoptotic and antiapoptotic proteins can homodimerise and heterodimerise and titrate one another's function, suggesting that their relative concentrations determine cell fate. ${ }^{8}$ Protection from apoptosis can be differentially provided by Bcl-2 or Bcl- $\mathrm{x}_{\mathrm{L}}$, depending on the cell type and type of apoptosis induction..$^{9-11}$

Although the incidence of cervical cancer in industrialised countries has decreased with the advent of systematic screening, it is still the second most frequent cause of death from cancer in women aged 20-39. ${ }^{12}$ Nearly half of patients present with stage I disease and adjuvant treatment is given to about one third of patients primarily treated with surgery. ${ }^{13}$ This adjuvant treatment is accompanied by considerable morbidity, ${ }^{14}$ and treating the many for the benefit of the few is undesirable. Thus, it would be useful to identify prognostic factors that could help target adjuvant treatment. Risk grouping can be done on the basis of clinical factors, ${ }^{15}$ but biomolecular factors may improve these prognostic models.

The aim of our study was to describe the expression of the $\mathrm{Bcl}-2, \mathrm{Bcl}-\mathrm{x}_{\mathrm{L}}$, and Bax proteins, and their prognostic value in early squamous cervical carcinoma (SCC).

\section{MATERIALS AND METHODS \\ Materials}

From January 1987 to December 1993, 242 patients with International Federation of Gynaecology and Obstetrics (FIGO) stage IB SCC (tumours clinically limited to the cervix and with invasion depth of $\geqslant 5 \mathrm{~mm}$ or horizontal spread of $\geqslant 7 \mathrm{~mm}$ ) were treated by radical hysterectomy and bilateral pelvic lymphadenectomy at the Norwegian Radium Hospital, Oslo, Norway. All cervical carcinomas diagnosed within the catchment area of the hospital are treated solely at this institution. All patients were examined under general anaesthesia and tumour diameter was assessed by inspection and palpation. No preoperative screening for lymph node metastasis was done. Our study comprises the 220 patients for whom sufficient pathological material was available. Postoperatively, adjuvant treatment was given in the case of lymph node metastasis, large tumour diameter, or invasion into the parametria. A median of 26 lymph nodes were

Abbreviations: SCC, squamous cervical carcinoma 
Table 1 Five year disease free (DFS) and disease specific (DSS) survival

\begin{tabular}{|c|c|c|c|c|c|c|c|}
\hline & Total $(n=220)$ & Relapses $(n=44$ ) & DFS & $\mathrm{p}$ Value & Deaths $(n=37)$ & DSS & $\mathrm{p}$ Value \\
\hline \multicolumn{8}{|c|}{ Bcl-2 expression } \\
\hline Low & 159 & $35(22 \%)$ & $80 \%$ & 0.20 & $29(18 \%)$ & $85 \%$ & 0.46 \\
\hline High & 61 & $9(15 \%)$ & $85 \%$ & & $8(13 \%)$ & $88 \%$ & \\
\hline \multicolumn{8}{|c|}{ Bcl- $x_{L}$ expression } \\
\hline Low & 193 & $39(20 \%)$ & $81 \%$ & 0.68 & $34(18 \%)$ & $85 \%$ & 0.61 \\
\hline High & 27 & $5(18.5 \%)$ & $85 \%$ & & $3(11 \%)$ & $89 \%$ & \\
\hline \multicolumn{8}{|l|}{ Bax expression } \\
\hline Low & 39 & $4(10 \%)$ & $90 \%$ & 0.09 & $4(10 \%)$ & $90 \%$ & 0.25 \\
\hline High & 181 & $40(22 \%)$ & $80 \%$ & & $33(18 \%)$ & $85 \%$ & \\
\hline \multicolumn{8}{|c|}{ Depth of invasion } \\
\hline$\leqslant 10 \mathrm{~mm}$ & 125 & $15(12 \%)$ & $93 \%$ & $<0.0001$ & $10(8 \%)$ & $93 \%$ & $<0.0001$ \\
\hline $11-15 \mathrm{~mm}$ & 48 & $8(17 \%)$ & $81 \%$ & & $8(17 \%)$ & $85 \%$ & \\
\hline$>15 \mathrm{~mm}$ & 47 & $21(45 \%)$ & $65 \%$ & & $19(40 \%)$ & $68 \%$ & \\
\hline \multicolumn{8}{|l|}{ Tumour size } \\
\hline$<2 \mathrm{~cm}$ & 100 & $12(12 \%)$ & $90 \%$ & 0.0002 & $9(9 \%)$ & $94 \%$ & 0.0003 \\
\hline $2.0-3.9 \mathrm{~cm}$ & 86 & $19(22 \%)$ & $80 \%$ & & $17(20 \%)$ & $84 \%$ & \\
\hline$\geqslant 4 \mathrm{~cm}$ & 34 & $13(38 \%)$ & $62 \%$ & & 11 (32\%) & $68 \%$ & \\
\hline \multicolumn{8}{|c|}{ Vascular invasion } \\
\hline Absent & 119 & $14(12 \%)$ & $91 \%$ & 0.0006 & $10(8 \%)$ & $92 \%$ & 0.0006 \\
\hline Present & 101 & $30(30 \%)$ & $76 \%$ & & $27(27 \%)$ & $79 \%$ & \\
\hline \multicolumn{8}{|c|}{ Parametrial invasion } \\
\hline Absent & 205 & $36(18 \%)$ & $83 \%$ & 0.0003 & $30(15 \%)$ & $87 \%$ & 0.0009 \\
\hline Present & 15 & $8(53 \%)$ & $60 \%$ & & $7(47 \%)$ & $67 \%$ & \\
\hline \multicolumn{8}{|c|}{ Lymph node metastasis } \\
\hline Absent & 178 & $28(16 \%)$ & $85 \%$ & 0.0012 & $21(12 \%)$ & $89 \%$ & $<0.0001$ \\
\hline Present & 42 & $16(38 \%)$ & $69 \%$ & & $16(38 \%)$ & $74 \%$ & \\
\hline
\end{tabular}

removed. Radiotherapy was given to 32 patients, radiation and chemotherapy to 12 , and another 31 received chemotherapy only. Patients were followed until July 2001 and none was lost to follow up. During follow up, 44 (19.7\%) patients had a relapse and $37(16.6 \%)$ died of cervical cancer (another four died of other diseases, five of unknown causes after a long period without relapse, and one of postoperative complications). All patients who experienced a relapse were admitted to our institution. Median follow up for patients without relapse was 128 months (interquartile range, 112-146), and for patients still alive it was 129 months (interquartile range, 114-147). The median age was 39 years (interquartile range, 34-51). Table 1 provides a detailed description of the tumour characteristics. As normal controls we used sections from formalin fixed, paraffin wax embedded tissue from 10 normal cervices from patients who underwent hysterectomy for prolapse (age range, 31-49 years; median age, 43). The specimens were reevaluated blindly by an experienced pathologist (KL) for histopathological diagnosis according to the World Health Organisation. ${ }^{16}$

\section{Immunohistochemistry}

Sections from formalin fixed, paraffin wax embedded blocks were immunostained using the biotin-streptavidin-peroxidase method (Supersensitive Immunodetection System, LPUL; Biogenex, San Ramon, California, USA) and the OptiMax Plus automated cell staining system (Biogenex). Dewaxed sections for Bcl-2, Bcl- $\mathrm{x}_{\mathrm{L}}$, and Bax staining were microwaved in $10 \mathrm{mM}$ citrate buffer ( $\mathrm{pH}$ 6.0) to unmask the epitopes. Sections were treated with $1 \% \mathrm{H}_{2} \mathrm{O}_{2}$ for 10 minutes to block endogenous peroxidase. The sections were then incubated with monoclonal antibodies against $\mathrm{Bcl}-2$ (1/20 dilution; $10 \mu \mathrm{g} \mathrm{IgG} / \mathrm{ml}$; Dako Cytomation, Glostrup, Denmark), Bcl- $\mathrm{X}_{\mathrm{L}}$ ( $1 / 25$ dilution; $2 \mu \mathrm{g} \mathrm{IgG} \mathrm{I}_{2 \mathrm{a}} / \mathrm{ml}$; Zymed Laboratories, South San Francisco, California, USA), and Bax (1/100 dilution; $2 \mu \mathrm{g}$ $\mathrm{IgG}_{\mathrm{l}} / \mathrm{ml}$; Neomarkers, Freemont, California, USA) for 30 minutes at room temperature. The sections were then incubated with biotin labelled secondary antibody (1/30 dilution) and streptavidin-biotin-peroxidase (1/30 dilution) for 20 minutes each. Tissue was stained for five minutes with $\quad 0.05 \% \quad 3,3^{\prime}$-diaminobenzidine tetrahydrochloride, freshly prepared in $0.05 \mathrm{M}$ Tris buffer ( $\mathrm{pH} 7.6$ ) containing $0.024 \% \mathrm{H}_{2} \mathrm{O}_{2}$, and then counterstained with haematoxylin, dehydrated, and mounted in Diatex. All the dilutions of antibody, biotin labelled secondary antibody, and streptavidin-peroxidase were made with phosphate buffered saline (pH 7.4) containing $1 \%$ bovine serum albumin. All series included positive controls. Replacement of the monoclonal antibody with mouse myeloma protein of the same subclass and concentration was used as negative control. All controls gave satisfactory results. Only cytoplasmic staining was considered positive. Four classes were used to describe the number of positively stained tumour cells: none; <5\% positive; between $5 \%$ and $50 \%$ positive; $>50 \%$ positive. Protein expression was defined as low when $<5 \%$ of cells were positive for Bcl-2, Bcl- $\mathrm{x}_{\mathrm{L}}$, and Bax. This was based on published data ${ }^{17}$ or the distribution pattern in normal squamous epithelium and cancer tissue. We later verified all other cutoff values in our data. One entire section was screened independently by two investigators ( $\mathrm{RH}$ and GVdP), unaware of the outcome. All discordant scores were reassessed and a single score agreed upon.

\section{STATISTICAL ANALYSIS}

The association between the expressed proteins and between protein expression and clinicopathological parameters was tested by means of the $\chi^{2}$ test with the Yates continuity correction for $2 \times 2$ tables or Fisher's exact test. For continuous data, the Mann-Whitney test was used. Disease free survival and disease specific survival rates were calculated from the date of first admission to relapse or death, respectively, or to 17 July 2001 using the method of Kaplan and Meier. The log rank test with a test for trend in case of ordered variables was used for univariate analysis, and a Cox proportional hazards regression model was used for multivariate analysis of survival. All variables with $\mathrm{p}<0.1$ in the univariate analysis were entered into the regression model and a backward stepwise procedure was used. The hazard proportionality was verified by computing the log minus log against time. The SPSS ${ }^{\circledR}$ statistical package 

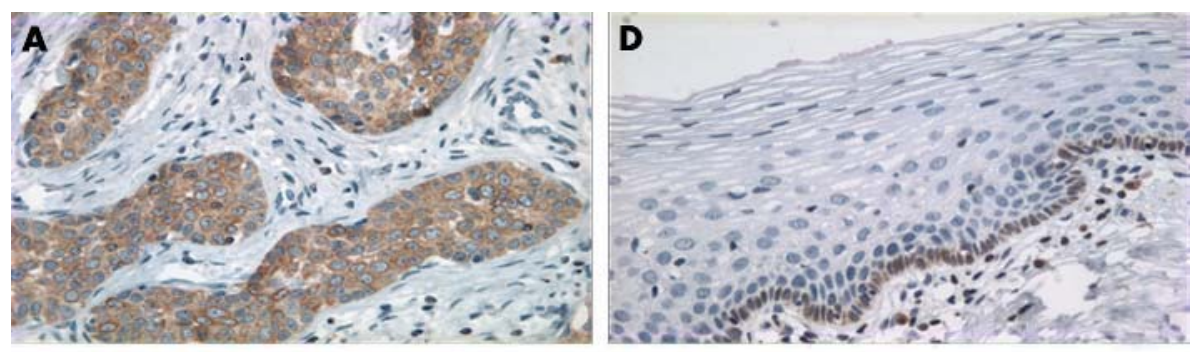

Figure 1 Immunohistochemical staining for $(A) B C l-2$, (B) $B C l-x_{L}$, and (C) Bax in early squamous cervical carcinomas; staining for (D) Bcl-2, (E) BCl- $\mathrm{x}_{\mathrm{L}}$, and (F) Bax in normal squamous epithelium.
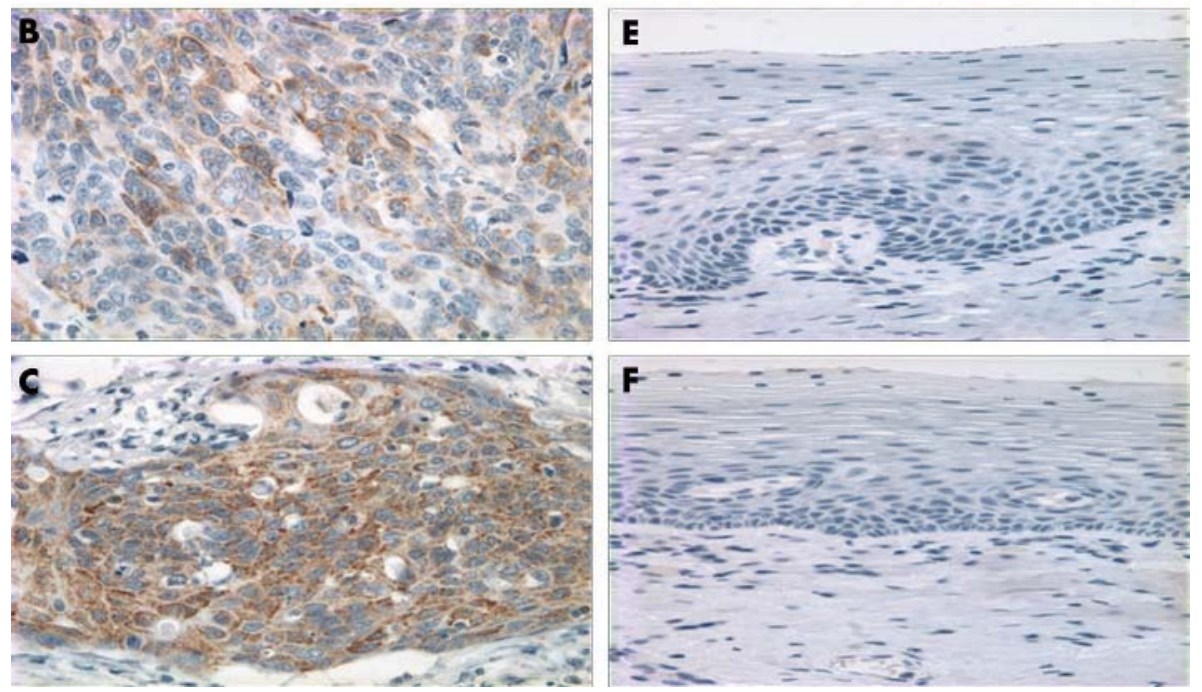

was used for statistical analysis and significance was defined as $\mathrm{p}<0.05$.

Power calculation: we needed 42 events to detect a difference of $15 \%(90 \% \vee 75 \%)$ in disease free survival at the $5 \%$ level with $90 \%$ power.

\section{RESULTS}

\section{Immunohistochemistry}

Table 2 summarises the staining results in SCC. Cytoplasmic expression of $\mathrm{Bcl}-2, \mathrm{Bcl}-\mathrm{x}_{\mathrm{L}}$, and $\mathrm{Bax}$ was low $(<5 \%$ positive cells) in 159 of $220(73 \%), 193$ of $220(87 \%)$, and 39 of 220 $(18 \%)$ tumours, respectively, and high ( $\geqslant 5 \%$ positive cells) in 61 of $220(27 \%), 27$ of $220(13 \%)$, and 181 of $220(82 \%)$ tumours, respectively (fig $1 \mathrm{~A}-\mathrm{C}$ ). In normal squamous epithelium, Bcl-2 expression was absent in two cases and present in less than $5 \%$ of cells in eight cases. Bcl-2 staining was limited to the basal layers. Bcl- $\mathrm{x}_{\mathrm{L}}$ and Bax were not expressed (fig 1D-F).

\section{Relation between the apoptotic markers}

Bcl-2 was significantly related to $B c l-x_{L}$ (Spearman $\rho=0.284 ; \mathrm{p}<0.0001$ ) and $\operatorname{Bax}($ Spearman $\rho=0.145$; $\mathrm{p}=0.032$.

\section{Protein expression in relation to clinicopathological parameters}

High Bax expression was associated with large tumour size $(\mathrm{p}=0.03)$ and there was a trend to an association with deep invasion $(\mathrm{p}=0.05 \mathrm{l})$. Bcl-2 and Bcl- $\mathrm{x}_{\mathrm{L}}$ expression were not associated with these parameters.

\section{Relation to survival}

Table 1 shows the relation between the clinicopathological and immunohistochemical data and survival in univariate analysis.

None of the markers for apoptosis showed a correlation with survival. In addition, other cutoff values for the single proteins did not reach significance. We then combined proapoptotic and antiapoptotic proteins, namely: high Bcl-2 or Bcl- $\mathrm{x}_{\mathrm{L}}$ with low Bax; low Bcl-2 or Bcl- $\mathrm{X}_{\mathrm{L}}$ with high Bax; high Bcl-2 and Bcl- $\mathrm{x}_{\mathrm{L}}$ with low Bax; and low Bcl-2 and Bcl- $\mathrm{x}_{\mathrm{L}}$ with high Bax. None of these combinations reached significance. Depth of invasion, pelvic lymph node metastasis, tumour diameter, parametrial invasion, and vascular invasion were significantly associated with survival. In the multivariate analysis, all variables with $\mathrm{p}<0.1$ were entered into the model except for tumour size because of the strong correlation with stromal invasion. Deep stromal invasion was

Table 2 Staining results for squamous cervical carcinoma

\begin{tabular}{|c|c|c|c|c|c|c|}
\hline \multirow[b]{2}{*}{ Per cent of cells stained } & \multicolumn{2}{|l|}{ Bcl-2 } & \multicolumn{2}{|c|}{$B c l-x_{L}$} & \multicolumn{2}{|l|}{ Bax } \\
\hline & $N$ & $\%$ & $\mathrm{~N}$ & $\%$ & $\mathrm{~N}$ & $\%$ \\
\hline $\begin{array}{l}0 \\
<5 \% \\
5-50 \% \\
>50 \% \\
\text { Total }\end{array}$ & $\begin{array}{r}131 \\
28 \\
47 \\
14 \\
220\end{array}$ & $\begin{array}{l}(60 \%) \\
(13 \%) \\
(21 \%) \\
(6 \%) \\
(100 \%)\end{array}$ & $\begin{array}{r}168 \\
25 \\
21 \\
6 \\
220\end{array}$ & $\begin{array}{l}(76 \%) \\
(11 \%) \\
(10 \%) \\
(3 \%) \\
(100 \%)\end{array}$ & $\begin{array}{r}14 \\
25 \\
91 \\
90 \\
220\end{array}$ & $\begin{array}{l}(6 \%) \\
(11 \%) \\
(41 \%) \\
(41 \%) \\
(100 \%)\end{array}$ \\
\hline
\end{tabular}


the only independent predictor for disease free survival $(p<0.0001)$ and overall survival $(p<0.0001)$.

\section{DISCUSSION}

The relation of the clinicopathological parameters to survival, and the possible explanations for the mere trend to significance of lymph node metastasis have been discussed in a previous study. ${ }^{18}$

Bcl-2 expression is increased in SCC compared with normal cervical epithelium, and using $5 \%$ as a cutoff, $27 \%$ of tumours showed Bcl-2 expression. The rate of Bcl-2 expression in early stage SCC in the literature ranges from $20 \%$ to $61 \% .{ }^{17}{ }^{19-23}$

The prognostic value of Bcl-2 in SCC is controversial, with reports describing Bcl-2 as a prognostic factor for improved survival, ${ }^{1722} 2425$ decreased survival, ${ }^{26}$ or as having no prognostic relevance. ${ }^{19-21} 2728$ This applies both for early stages with surgery as the primary treatment and for advanced stages, treated by radiotherapy. Although one could focus on the differences between the techniques used (Ferrandina et al used western blotting ${ }^{28}$ ) or the differences in cutoff values used (only the 30\% cutoff value used by Graflund and colleagues $^{19}$ and Pillai and colleagues ${ }^{25}$ really differs), the explanation for the differences is probably the lack of the validation of prognostic factors in general, which would have disclosed the "data derived" nature of these studies. ${ }^{29}$ Comparing the most significant study by Tjalma and colleagues ${ }^{17}$ with ours, a very similar technique and the same cutoff values were used. In that study, Bcl-2 looked very promising, but the study was explorative and the cutoff values were data derived. Such an approach is not objectionable, as long as one bears in mind that it is only hypothesis generating, which means that the results might be true only for the examined dataset. In this context, it is imperative that such studies should be repeated in an independent population. We could not confirm these results in our independent population, providing strong evidence against the usefulness of Bcl-2 as an independent prognostic factor in stage IB SCC. Other differences between these studies are the low survival rates and the omission of tumour size or invasion depth in the multivariate analysis in the study by Tjalma et al. ${ }^{17}$

We did not find prognostic significance for $\mathrm{Bcl}-\mathrm{x}_{\mathrm{L}}$. Bcl- $\mathrm{x}_{\mathrm{L}}$ protein expression has not previously been analysed by means of immunohistochemistry. No prognostic significance was found in two studies using western blotting. ${ }^{28}{ }^{30}$ In these studies, Bcl- $\mathrm{X}_{\mathrm{L}}$ expression in SCC was not different from that seen in normal tissue.

In our study, $82 \%$ of tumours showed Bax expression, which is similar to the $83 \%$ and $72 \%$ found in two other studies $^{24}{ }^{31}$ using a cutoff value of $10 \%$. In agreement with most previous studies, ${ }^{24} 28{ }^{30}{ }^{31}$ we did not find Bax expression to be of prognostic value. As mentioned, Ferrandina et al and Mozzetti et al used western blotting. ${ }^{28} 30$

Because proapoptotic proteins mainly act through heterodimerisation with antiapoptotic proteins, it is their relative concentration that might act as a rheostat for apoptosis. ${ }^{8}$ Therefore, we examined the proapoptotic to antiapoptotic ratio for its prognostic value; however, no significant

\section{Take home messages}

- The antiapoptotic proteins, $\mathrm{Bcl}-2$ and $\mathrm{Bcl}-\mathrm{x}_{\mathrm{L}}$, and the proapoptotic protein Bax were not independently associated with prognosis in stage IB squamous cervical carcinoma

- These apoptosis regulatory proteins have no prognostic value in this disease association with survival was found. In addition, measuring the whole process of apoptosis by surface morphology and composition, nuclear events and DNA cleavage, cytoplasmic biochemical activation events (such as caspase activity), cell dissolution, or mitochondrial function has been disappointing in determining prognosis. ${ }^{20} 32$

In conclusion, in this adequately powered study, none of the investigated proteins- $\mathrm{Bcl}-2, \mathrm{Bcl}-\mathrm{X}_{\mathrm{L}}$ and $\mathrm{Bax}$-was independently associated with prognosis.

\section{ACKNOWLEDGEMENTS}

We thank M T P Nguyen for excellent technical assistance. Supported in part by grants from the Norwegian Cancer Society.

\section{Authors' affiliations}

G V de Putte, M Baekelandt, G B Kristensen, Department of Gynaecological Oncology, The Norwegian Radium Hospital, Montebello, 0310 Oslo, Norway

R Holm, A K Lie, Department of Pathology, The Norwegian Radium Hospital

\section{REFERENCES}

1 Kerr JF, Wyllie AH, Currie AR. Apoptosis: a basic biological phenomenon with wide-ranging implications in tissue kinetics. $\mathrm{Br} J$ Cancer 1972;26:239-57.

2 Vaux DL, Cory S, Adams JM. Bcl-2 gene promotes haemopoietic cell survival and cooperates with c-myc to immortalize pre-B cells. Nature 1988;335:440-2.

3 Tsujimoto $Y$, Finger LR, Yunis J, et al. Cloning of the chromosome breakpoint of neoplastic $B$ cells with the $\dagger(14 ; 18)$ chromosome translocation. Science 1984;226:1097-9.

4 White E. Life, death, and the pursuit of apoptosis. Genes Dev 1996;10:1-15.

5 Miyashita T, Reed JC. Bcl-2 oncoprotein blocks chemotherapy-induced apoptosis in a human leukemia cell line. Blood 1993;81:151-7.

6 Boise LH, Gonzalez-Garcia M, Postema CE, et al. bcl-x, a bcl-2-related gene that functions as a dominant regulator of apoptotic cell death. Cell 1993; 74:597-608.

7 Jurgensmeier JM, Xie Z, Deveraux $Q$, et al. Bax directly induces release of cytochrome c from isolated mitochondria. Proc Natl Acad Sci U S A 1998;95:4997-5002

8 Oltvai ZN, Milliman CL, Korsmeyer SJ. Bcl-2 heterodimerizes in vivo with a conserved homolog, Bax, that accelerates programmed cell death. Cell 1993;74:609-19

9 Findley HW, Gu L, Yeager AM, et al. Expression and regulation of $\mathrm{BCl}-2, \mathrm{Bcl}-$ $\mathrm{xl}$, and Bax correlate with $\mathrm{p} 53$ status and sensitivity to apoptosis in childhood acute lymphoblastic leukemia. Blood 1997;89:2986-93.

10 Park JR, Bernstein ID, Hockenbery DM. Primitive human hematopoietic precursors express Bcl-x but not Bcl-2. Blood 1995;86:868-76.

11 Ma A, Pena JC, Chang B, et al. Bclx regulates the survival of double-positive thymocytes. Proc Natl Acad Sci U S A 1995;92:4763-7.

12 Jemal A, Murray T, Samuels A, et al. Cancer statistics, 2003. CA Cancer J Clin 2003;53:5-26.

13 Benedet JL, Odicino F, Maisonneuve $\mathrm{P}$, et al. Carcinoma of the cervix uteri. $J$ Epidemiol Biostat $2001 ; 6: 7-43$

14 Landoni F, Maneo A, Colombo A, et al. Randomised study of radical surgery versus radiotherapy for stage Ib-lla cervical cancer. Lancet 1997; 350:535-40.

15 Sedlis A, Bundy $B N$, Rotman $M Z$, et al. A randomized trial of pelvic radiation therapy versus no further therapy in selected patients with stage IB carcinoma of the cervix after radical hysterectomy and pelvic lymphadenectomy: a gynecologic oncology group study. Gynecol Oncol 1999;73:177-83.

16 Poulsen HE, Taylor CW, Sobin LH. Histological typing of female genital tract tumours, International histological classification of tumours. Geneva: World Health Organisation, 1975.

17 Tjalma W, Weyler J, Goovaerts G, et al. Prognostic value of bcl-2 expression in patients with operable carcinoma of the uterine cervix. J Clin Pathol 1997;50:33-6.

18 van de Putte G, Holm R, Lie AK, et al. Expression of p27, p21 and p16 protein in early squamous cervical cancer and its relation to prognosis. Gynecol Oncol 2003:89:140-7.

19 Graflund M, Sorbe B, Karlsson M. Immunohistochemical expression of p53, bcl-2, and p21(WAF1 /CIP1) in early cervical carcinoma: correlation with clinical outcome. Int J Gynecol Cancer 2002;12:290-8.

20 Jain D, Srinivasan R, Patel FD, et al. Evaluation of $\mathrm{p} 53$ and $B c l-2$ expression as prognostic markers in invasive cervical carcinoma stage $\mathrm{llb} / \mathrm{III}$ patients treated by radiotherapy. Gynecol Oncol 2003;88:22-8.

21 Uehara T, Kuwashima Y, Izumo T, et al. Expression of the proto-oncogene bcl2 in uterine cervical squamous cell carcinoma: its relationship to clinical outcome. Eur J Gynaecol Oncol 1995;16:453-60.

22 Dimitrakakis C, Kymionis G, Diakomanolis E, et al. The possible role of p53 and bcl-2 expression in cervical carcinomas and their premalignant lesions. Gynecol Oncol 2000;77:129-36. 
23 Saegusa $M$, Takano $Y$, Hashimura $M$, et al. The possible role of bcl-2 expression in the progression of tumors of the uterine cervix. Cancer 1995;76:2297-303.

24 Crawford RA, Caldwell C, lles RK, et al. Prognostic significance of the bcl-2 apoptotic family of proteins in primary and recurrent cervical cancer. Br J Cancer 1998;78:210-14.

25 Pillai MR, Jayaprakash PG, Nair MK. Bcl-2 immunoreactivity but not p53 accumulation associated with tumour response to radiotherapy in cervical carcinoma. J Cancer Res Clin Oncol 1999;125:55-60.

26 Rajkumar T, Rajan S, Baruah RK, et al. Prognostic significance of $\mathrm{Bcl}-2$ and p53 protein expression in stage IIB and IIIB squamous cell carcinoma of the cervix. Eur J Gynaecol Oncol 1998; 19:556-60.

27 Chung TK, Cheung TH, Lo WK, et al. Expression of apoptotic regulators and their significance in cervical cancer. Cancer Lett 2002;180:63-8.
28 Ferrandina G, Mozzetti S, Marone M, et al. Bcl-2, bax, bcl-x (L) and bcl-x (S) expression in neoplastic and normal cervical tissue. Cancer Lett 2000;155:19-27.

29 Altman DG, Royston P. What do we mean by validating a prognostic model? Stat Med 2000;19:453-73.

30 Mozzetti S, Ferrandina G, Marone M, et al. Expression of bcl-2, bax-xL, and $\mathrm{bcl}-\mathrm{xS}$ in endometrial and cervical tissues. Cancer Detect Prev 2000;24:536-41.

31 Tjalma WA, Weyler JJ, Bogers JJ, et al. The importance of biological factors (bcl-2, bax, p53, PCNA, Ml, HPV and angiogenesis) in invasive cervical cancer. Eur J Obstet Gynecol Reprod Biol 2001;97:223-30.

32 Paxton JR, Bolger BS, Armour A, et al. Apoptosis in cervical squamous carcinoma: predictive value for survival following radiotherapy. J Clin Pathol 2000;53:197-200.

\section{Clinical Evidence - Call for contributors}

Clinical Evidence is a regularly updated evidence-based journal available worldwide both as a paper version and on the internet. Clinical Evidence needs to recruit a number of new contributors. Contributors are healthcare professionals or epidemiologists with experience in evidence-based medicine and the ability to write in a concise and structured way.

Areas for which we are currently seeking authors:

- Child health: nocturnal enuresis

- Eye disorders: bacterial conjunctivitis

- Male health: prostate cancer (metastatic)

- Women's health: pre-menstrual syndrome; pyelonephritis in non-pregnant women However, we are always looking for others, so do not let this list discourage you.

Being a contributor involves:

- Selecting from a validated, screened search (performed by in-house Information Specialists) epidemiologically sound studies for inclusion.

- Documenting your decisions about which studies to include on an inclusion and exclusion form, which we keep on file.

- Writing the text to a highly structured template (about 1500-3000 words), using evidence from the final studies chosen, within 8-10 weeks of receiving the literature search.

- Working with Clinical Evidence editors to ensure that the final text meets epidemiological and style standards.

- Updating the text every six months using any new, sound evidence that becomes available. The Clinical Evidence in-house team will conduct the searches for contributors; your task is simply to filter out high quality studies and incorporate them in the existing text.

- To expand the topic to include a new question about once every 12-18 months.

If you would like to become a contributor for Clinical Evidence or require more information about what this involves please send your contact details and a copy of your CV, clearly stating the clinical area you are interested in, to Klara Brunnhuber (kbrunnhuber@ bmigroup.com).

\section{Call for peer reviewers}

Clinical Evidence also needs to recruit a number of new peer reviewers specifically with an interest in the clinical areas stated above, and also others related to general practice. Peer reviewers are healthcare professionals or epidemiologists with experience in evidence-based medicine. As a peer reviewer you would be asked for your views on the clinical relevance, validity, and accessibility of specific topics within the journal, and their usefulness to the intended audience (international generalists and healthcare professionals, possibly with limited statistical knowledge). Topics are usually 1500-3000 words in length and we would ask you to review between 2-5 topics per year. The peer review process takes place throughout the year, and our turnaround time for each review is ideally 10-14 days.

If you are interested in becoming a peer reviewer for Clinical Evidence, please complete the peer review questionnaire at www.clinicalevidence.com or contact Klara Brunnhuber (kbrunnhuber@bmigroup.com). 